\title{
Supporting or resisting? The relationship between global north states and special procedures
}

Book or Report Section

Accepted Version

Freedman, R. and Crepeau, F. (2017) Supporting or resisting? The relationship between global north states and special procedures. In: Nolan, A., Freedman, R. and Murphy, T. (eds.) The United Nations Special Procedures System. Nottingham Studies on Human Rights. Brill. ISBN 9789004304697 Available at https://centaur.reading.ac.uk/66569/

It is advisable to refer to the publisher's version if you intend to cite from the work. See Guidance on citing.

Publisher: Brill

All outputs in CentAUR are protected by Intellectual Property Rights law, including copyright law. Copyright and IPR is retained by the creators or other copyright holders. Terms and conditions for use of this material are defined in the End User Agreement.

www.reading.ac.uk/centaur 
Central Archive at the University of Reading

Reading's research outputs online 


\section{Supporting or Resisting? \\ The Relationship between Global North States and Special Procedures \\ Rosa Freedman* and Francois Crépeau}

\section{Introduction}

Scrutiny of the relationship between Special Procedures and States typically focuses on mandate holders' independence and expertise, as well as the impact of their work 'on the ground'. Global South countries have been criticised for ignoring visit requests, resisting recommendations contained within reports and seeking to undermine Special Procedures by introducing new, vague mandates on subjects not traditionally viewed as falling within the human rights matrix. Little attention, however, has been paid to the relationship between Global North States and Special Procedures.

Global North States ${ }^{1}$ have typically supported Special Procedures, both in terms of creating mandates and providing financial support for their activities. The initial mandates focussed on civil and political rights, a category which ties in with Western notions of how legal mechanisms may be utilised to protect and promote human rights. From the outset of thematic mandates, Global North States have been at the fore of sponsoring, promoting and voting for the creation and renewal of mandates, ${ }^{2}$ viewing Special Procedures as a crucial tool for promoting and protecting rights. Financial contributions to Special Procedures reflect the esteem with which Global North States hold mandates, with significant resources donated by many of those countries especially when compared with contributions from other States. ${ }^{3}$ Moreover, until recently the mandate holders overwhelmingly were likely to come from Global North countries, either in terms of nationality or places of employment. While there

\footnotetext{
* This work was supported by the British Academy (grant number SG132479).

${ }^{1}$ The division between Global North and Global South is typically defined along socio-economic lines, with frequent references to development indicators. Global North generally refers to countries from Western Europe, alongside some from Eastern Europe that are members of the European Union, North America and other more developed countries, such as Japan, Israel and South Africa. The division between South and North in this manner is not uncontentious, as indeed are similar divisions along regional or political lines, but is a useful (albeit limited) tool for understanding State interactions and engagement within the international arena. We argue in this chapter that there are clearly discernible patterns in State activities regarding Special Procedures that can be categorised along North-South lines and that it is important to focus on how some Global North States respond to some types of mandate holders in order to highlight and address those responses.

${ }^{2}$ For more on this point see R Freedman and J Mchangama, 'Expanding or Diluting Human Rights?: The Proliferation of United Nations Special Procedures Mandates' (2016) 30 Human Rights Quarterly 1, 164-193.

${ }^{3}$ For the most recent detailed breakdown of voluntary contributions given by States, including earmarked and unearmarked funds, see OHCHR, 'Report 2014 - Funding' (2015) available at http://www2.ohchr.org/english/OHCHRReport2014/WEB_version/allegati/5_Funding_2014.pdf in particular 68-73, accessed 3 April 2016. See also Connors' chapter in this collection.
} 
was always disproportionate scrutiny by mandate holders of Global North States, ${ }^{4}$ perhaps owing to a greater accessibility to those countries, until recently there was no more resistance to Special Procedures' reports from such States than might be expected from any country that is criticised for its human rights record.

The changing nature of some Global North States' response and reaction to mandate holders' visits and reports has developed since the turn of the Millennium and has picked up speed since the Human Rights Council's creation in 2006. There have been a number of very public incidents where particular Global North countries have refused to allow mandate holders unfettered access to undertake their work or have reacted negatively, and frequently erroneously, to criticisms levelled in mandate holders' reports. While this has not yet impacted upon Global North countries' relationship with the Special Procedures system as a whole in terms of financial contributions ${ }^{5}$ or positive responses to visit requests, it is crucial to understand why those States are becoming increasingly resistant to some mandate holders.

This chapter will interrogate the relationship between Global North countries and mandate holders, individually, and the system more broadly. It will first set out the ways in which Special Procedures uphold the nature of international human rights, particularly in relation to universality and to the interdependence, interrelatedness and indivisibility of human rights. It will then turn to the forms of resistance that a number of Global North States have taken regarding certain types of mandates, before exploring potential motivations and reasons for that resistance. Using four case studies - the UK and adequate housing, Canada and food, the EU and migrants, the US and poverty - we shall explore the ways in which some Global North States have resisted and undermined particular mandate holders' activities. Analysis will focus on the reasons for that resistance, which challenge the principle of universality of human rights. In particular, we shall highlight the ideological divisions that remain, despite Global North States paying lip service to the indivisibility of human rights. As well, we shall document the increasingly frequent political attitude of a growing number of Global North States who insist that, considering their human rights record, they ought not to be visited and criticised by Special Procedures mandate holders, who should rather concentrate their energy on States with much worse human rights records.

\footnotetext{
4 The statistics on country visits undertaken by mandate holders since 1998 are available on the OHCHR website <www.ohchr.org/EN/HRBodies/SP/Pages/countryvisitsa-e.aspx> accessed 3 April 2016 and demonstrate that the majority of thematic visits have been undertaken in Global North countries, despite those States comprising a significant minority of UN member States.

${ }^{5}$ See (n 3) for statistics on voluntary contributions.
} 


\section{Special Procedures and the nature of human rights}

The role that the Special Procedures system plays in protecting and promoting human rights reflects a key principle of international human rights law that rights are (i) universal and (ii) interdependent, interrelated and indivisible. ${ }^{6}$ The role of Special Procedures in protecting and promoting all types of rights universally is one that sets it apart from the UN treaty bodies and from the regional human rights judicial and quasi-judicial institutions. Those mechanisms only focus on States parties to the relevant treaties (UN or regional) that are monitored, protected and promoted by those bodies. Special Procedures mandates, in contrast, may focus on any country and may report on or engage with a State even if a mandate holder has not visited its territory. Where it comes to subject matter covered by mandates, the Special Procedures system has a far broader and more inclusive remit than any other human rights bodies. Treaty bodies and regional institutions, for example, may only focus on those rights falling within specific treaties whereas the Special Procedures system is more fluid, allowing new mandates to be created to protect and promote any right. And since the 1990s the system has increasingly reflected all categories of thematic rights. But that expansion has also brought greater resistance from Global North States, and it is important therefore to explore the types of mandates and those countries' responses to their creation before examining how some States have reacted to visits from mandate holders.

\section{A. Mandates and different categories of rights}

With the system developing ad hoc during the Cold War, Special Procedures did not always reflect the broad range of human rights within the international system. Indeed, the types of mandates have changed and expanded rapidly over the past 20 years. Special Procedures focussed almost exclusively on civil and political rights (CPR) until 1995 when the Commission on Human Rights created a third generation rights (TGR) mandate on Toxic Dumping. ${ }^{7}$ Since then, there has been a movement towards expanding the system to include

\footnotetext{
${ }^{6}$ See eg 'Vienna Declaration and Programme of Action' World Conference on Human Rights (Vienna 14-25 June 1993) (12 July 1993) UN Doc A/CONF.157/23, para 5: 'All human rights are universal, indivisible and interdependent and interrelated. The international community must treat human rights globally in a fair and equal manner, on the same footing, and with the same emphasis. While the significance of national and regional particularities and various historical, cultural and religious backgrounds must be borne in mind, it is the duty of States, regardless of their political, economic and cultural systems, to promote and protect all human rights and fundamental freedoms.'

${ }^{7}$ UNCHR Res 1995/81 'The Adverse Effects of the Illicit Movement and Dumping of Toxic and Dangerous Products and Wastes on the Enjoyment of Human Rights' (8 March 1995) UN Doc E/CN.4/1995/176.
} 
economic, social and cultural rights (ESCR) and TGR, adding some 12 ESCR mandates ${ }^{8}$ and four TGR mandates. ${ }^{9}$ The first two ESCR mandates were on Poverty ${ }^{10}$ and Education, ${ }^{11}$ both created in 1998. Between 1995 and 2013, five TGR mandates and 12 ESCR mandates have been adopted. In that time there have been four new CPR as traditionally understood, ${ }^{12}$ starting with Impunity in $2004 .{ }^{13}$ There have also been eight mandates, ${ }^{14}$ starting with Migrants in $1999,{ }^{15}$ where the resolution largely seeks to promote and protect CPR but only in relation to a specific or vulnerable group of people.

It is this expansion of the system that has both given greater legitimacy and credibility to Special Procedures but has also impacted upon the ways in which some Global North

\footnotetext{
${ }^{8}$ UNCHR Res 1998/25 'Human Rights and Extreme Poverty' (17 April 1998) UN Doc E/CN.4/1998/25; UNCHR Res 1998/33 'Right to Education' (17 April 1998) UN Doc E/CN.4/1998/33; UNCHR Res 2000/9 'Adequate Housing as a Component of the Right to an Adequate Standard of Living' (17 April 2000) UN Doc E/CN.4/2000/9; UNCHR Res 2000/10 'Right to Food' (17 April 2000) UN Doc E/CN.4/RES/2000/10; UNCHR Res 2000/82 'The Effects of Structural Adjustment Policies and Foreign Debt' (26 April 2000) UN Doc E/CN.4/RES/2000/82; UNCHR Res 2001/30 'Draft Optional Protocol to the International Covenant on Economic, Social and Cultural Rights' (20 April 2001) UN Doc E/CN.4/2001/30; UNCHR Res 2002/31 'Right of Everyone to the Enjoyment of the Highest Attainable Standard of Physical and Mental Health' (22 April 2002) UN Doc E/CN.4/RES/2002/31; UNCHR Res 2002/68 'People of African Descent' (25 April 2002) UN Doc E/CN.4/RES/2002/68; UNCHR Res 2005/69 'Human Rights and Transnational Corporations and other Business Enterprises' (20 April 2005) UN Doc E/CN.4/2005/69; UNHRC Res 7/22, 'Human Rights Obligations related to Access to Safe Drinking Water and Sanitation' (28 March 2008) UN Doc A/HRC/RES/7/22; UNHRC Res 10/23 'Cultural Rights' (26 March 2009) UN Doc A/HRC/RES/10/23; UNHRC Res 24/20 'The Human Rights of Older Persons' (27 September 2013) UN Doc A/HRC/RES/24/20.

9 UNCHR Res 1998/72 'Right to Development' (22 April 1998) UN Doc E/CN.4/1998/72; UNCHR Res 2005/55 'Human Rights and International Solidarity' (20 April 2005) UN Doc E/CN.4/2005/55; UNCHR Res 2005/57 'Promotion of a Democratic and Equitable International Order' (20 April 2005) UN Doc E/CN.4/RES/2005/57; UNHRC Res 19/10 'Human Rights Obligations related to the Enjoyment of a Safe, Clean, Healthy and Sustainable Environment' (22 March 2012) UN Doc A/HRC/RES/19/10.

${ }^{10}$ UNCHR Res 1998/25 'Human Rights and Extreme Poverty' (17 April 1998) UN Doc E/CN.4/1998/25. While this Resolution refers to human rights generally, the strong connections between poverty and ESCR enjoyment (or lack thereof) means that this mandate can legitimately be labelled 'ESCR' in nature.

${ }^{11}$ UNCHR Res 1998/33 'Question of the Realization in all Countries of the Economic, Social and Cultural Rights contained in the Universal Declaration of Human Rights and in the International Covenant on Economic, Social and Cultural Rights, and study of special problems which the developing countries face in their efforts to achieve these human rights' (17 April 1998) UN Doc E/CN.4/1998/33, para 6.

${ }^{12}$ UNCHR Res 2004/72 'Set of Principles for the Protection and Promotion of Human Rights through Action to Combat Impunity' (21 April 2004) UN Doc E/CN.4/2004/72; UNHRC Res 6/14 'Contemporary Forms of Slavery including its Causes and Consequences' (28 September 2007) UN Doc A/HRC/RES/6/14; UNHRC Res 15/21 'Freedom of Peaceful Assembly and of Association' (30 September 2010) UN Doc A/HRC/RES/15/21; UNHRC Res 18/7 'Promotion of Truth, Justice, Reparation \& Guarantees on Non-Recurrence' (29 September 2011) UN Doc A/HRC/RES/18/7.

${ }_{13}^{13}$ UNCHR Res 2004/72 'Impunity' (21 April 2004) UN Doc E/CN.4/2004/72.

${ }^{14}$ UNCHR Res 1999/44 'Human Rights of Migrants' (27 April 1999) UN Doc E/CN.4/1999/44; UNCHR Res 2000/61 'Human Rights Defenders' (26 April 2000) UN Doc E/CN.4/RES/2000/61; UNCHR Res 2001/57, 'Human Rights and Fundamental Freedoms of Indigenous People' (24 April 2001) UN Doc E/CN.4/RES/2001/57; UNCHR Res 2002/68 'People of African Descent' (25 April 2002) UN Doc E/CN.4/RES/2002/68; UNCHR Res 2004/110 'Trafficking in Persons Especially Women and Children' (21 April 2004) UN Doc E/CN.4/DEC/2004/110; UNCHR Res 2005/79 'Minority Issues' (21 April 2004) UN Doc E/CN.4/RES/2005/79; UNHRC Res 15/23 'Discrimination Against Women in Law and in Practice' (1 October 2010) UN Doc A/HRC/RES/15/23; UNHRC Res 24/20 'The Human Rights of Older Persons' (27 September 2013) UN Doc A/HRC/RES/24/20.

${ }^{15}$ UNCHR Res 1999/44 'Human Rights of Migrants’ 27 April 1999) UN Doc E/CN.4/1999/44.
} 
States engage with some individual mandate holders. Of course, Global North States are not homogenous and there is a broad spectrum in terms of approaches to ESCR and TGR, with countries such as Spain and Ireland taking markedly different approaches than for example the United States. ${ }^{16}$ Yet it is also clear that ESCR as legal rights are still criticised by some Global North States, while some others all but ignore ESCR as requiring legal protection. The US is not party to the International Covenant on Economic, Social and Cultural Rights; ${ }^{17}$ and, while other Global North countries have ratified that treaty, many have adopted a more intermediate position towards ESCR than CPR in terms of legal protection and legal mechanisms. The majority of Global North States have far fewer ESCR than CPR in their national constitutions, ${ }^{18}$ and/or differentiate between the legal status that they afford to ESCR and CPR. ${ }^{19}$.

The differences between approaches to CPR and ESCR are significant, but they are far less pronounced than the differences between those two categories of rights and TGR. Some TGR mandates bring into the human rights arena issues that are protected elsewhere, for example in relation to environmental law. ${ }^{20}$ However, within the human rights arena TGR typically remain at the embryonic stage of development in terms both of legal norms and of mechanisms available for protecting and promoting those rights. ${ }^{21}$ As we will see below, TGR generally are criticised by Global North States, many of which insist that they divert

\footnotetext{
16 'For an overview of a range of different national approaches, including those of a number of Gobal North States, see M Langford (ed), Social Rights Jurisprudence Emerging Trends in International and Comparative Law (CUP 2008); F. Coomans, (ed), Justiciability of Economic and Social Rights, Experiences from Domestic Systems (Intersentia, 2006).

${ }^{17}$ International Covenant on Economic, Social and Cultural Rights (adopted 16 December 1966, entered into force 3 January 1976) 993 UNTS 3.

${ }^{18}$ Even where Western governments have taken a position that supports the equal status and importance of ESCR in terms of their statements at the international level, they frequently fail to take legislative, administrative or judicial measures that would be entailed by a meaningful recognition and acceptable of ESCR as human rights or to provide effective redress for alleged violations of those rights, whether at the domestic or international level. For example, from the international perspective, at the time of writing only three Western democracies - Spain, Portugal and Slovakia - have ratified the Optional Protocol to the ICESCR. The following databases demonstrate that there is greater constitutional protection of CPR than ESCR: https://www.constituteproject.org/ and http://www.tiesr.org/data cr.html accessed 3 April 2016.

${ }^{19}$ For more on this point, see M Langford (ed), Social Rights Jurisprudence Emerging Trends in International and Comparative Law (CUP 2008).

${ }^{20}$ D Shelton, 'Environmental Rights' in P Alston (ed), People's Rights (OUP 2001) 194. Note that the only international human rights treaty to make explicit reference to aspects of environmental protection is the United Nations Convention on the Rights of the Child (adopted 20 November 1989, entered into force 2 September 1990) 1577 UNTS 3, art 24 (UNGA, 'Convention on the Rights of the Child', 20 November 1989, UNTS vol 1577, 3).

${ }^{21}$ See DN Sharp 'Re-Appraising the Significance of "Third-Generation" Rights in a Globalized World' (2015) available for download at <http://papers.ssrn.com/sol3/papers.cfm?abstract_id=2635236> 8-10, discussing the vague and broad content of TGR.
} 
resources away from other thematic areas, and also because arguably they focus on issue areas that are better addressed outside of the human rights system. ${ }^{22}$

In contrast, where it comes to international human rights law mechanisms that focus on vulnerable groups, Global North States generally support their creation and operation as we will see below. Although the essence of human rights being universal is that they apply equally to all persons irrespective of an individual's characteristics, it is clear that the ideals of universality do not always translate into practice where it comes to vulnerable groups. The problem, of course, is that the vulnerability of each category of people usually relates to national policies or approaches to those groups, and therefore different States have been resistant to focus on those groups that require the most assistance within their own territories. Although historically those mechanisms have focussed largely on groups that Global North States recognise as vulnerable, such as women, children and minorities, there have been more recent attempts to create mechanisms that move beyond those approaches - for example on Peasants $^{23}$ - that have not been supported by many of those countries.

\section{B. Global North States and different types of mandates}

Special Procedures' legitimacy depends on all types of States being examined on all types of rights in a proportionate and even-handed manner. Yet when it comes to some Global North States it appears that the increase in mandates on ESCR, TGR ${ }^{24}$ and vulnerable groups has impacted negatively upon those countries accepting the system's universality in terms of visits, reports and recommendations about human rights issues within their own territories. It is interesting to note the different types of resistance from different countries. One form of resistance, and indeed a key one, is through voting against the creation or renewal of a mandate. That sends a strong message about whether a State agrees that legal mechanisms are appropriate to protect or promote a right. When mandates are created or renewed, a resolution is tabled at the UN's principal human rights body - previously the Commission on Human

\footnotetext{
${ }^{22}$ See L Richardson, 'Economic, Social and Cultural Rights (and Beyond) in the UN Human Rights Council' (2015) 15 Human Rights Law Review 1, 21-22 discussing TGR and responses from HRC members.

${ }^{23}$ For a detailed discussion of peasants' rights and of various responses to those rights, see C Golay, 'Legal Reflections on the Rights of Peasants and Other People Working in Rural Areas - background paper prepared for the first session of the working group on the rights of peasants and other people working in rural areas' (Geneva Academy of International Humanitarian Law and Human Rights, 15-19 July 2013) <www.ohchr.org/Documents/HRBodies/HRCouncil/WGPleasants/Golay.pdf> accessed 3 April 2016.

${ }^{24}$ For more on the increase in the number of mandates, see Freedman and Mchangama (n 2) and M Limon and Hilary Power, 'History of the United Nations Special Procedures Mechanism: Origins, Evolution and Reform' (2014, Universal Rights Group), Annex I, available at http://www.universal-rights.org/urg-policyreports/history-of-the-united-nations-special-procedures-mechanism-origins-evolution-and-reform/ accessed 3 April 2016.
} 
Rights (CHR) and currently the Human Rights Council (HRC). States members of the body then vote either for or against the resolution or abstain from voting. Countries not members of the body may signal their support through sponsoring the resolution but are not able to vote on whether or not it passes.

The second form of resistance comes later in terms of how States respond to and engage with mandate holders, including accepting, rejecting or ignoring visit requests, providing unfettered access for fact-finding, responding to communications regarding individual complaints, and public responses to mandate holders within both the national and international arenas. In what follows we will explore Global North States' responses - which are not always homogenous - to the creation and renewal of mandates in order to provide a general map of the differences and similarities of those States' approaches to different types of mandates. That is crucial for understanding how and why some Global North States have pushed-back against some mandate holders, which will be explored in subsequent sections.

Global North States typically have not been resistant to the civil and political rights (CPR) mandates because those map onto their understandings of what constitutes legal rights in terms of justiciability and international legal mechanisms. As a result, CPR mandates are not as politically controversial as ESCR mandates from the perspective of many Global North States. CPR mandate holders explore issues relating mostly to law and its implementation through the justice system.

Where it comes to ESCR mandates most Global North States have voted for their creation and renewal, particularly European Union member States despite there being some divergence of opinion internally between those countries as we will see. However, the notable exception is the US, which when it was a member of the CHR voted against the creation of the mandates on Extreme Poverty (1998) ${ }^{25}$ and on the Right to Food (2000). ${ }^{26}$ In 2000, the Czech Republic and Latvia abstained in the vote, ${ }^{27}$ neither of which were members of the European Union at the time. In contrast, all EU Member States that sat at the CHR in 2000 voted for the creation of the mandate. ${ }^{28}$ None of the ESCR mandates have required a vote for their renewal, demonstrating that Global North States have accepted the mandates as mechanisms whose existence they do not resist. It is also interesting to note that the mandates

\footnotetext{
${ }^{25}$ UNCHR Res 1998/25 'Human Rights and Extreme Poverty’ (17 April 1998) UN Doc E/CN.4/RES/1998/25.

${ }^{26}$ UNCHR Res 2000/10 'The Right to Food' (17 April 2000) UN Doc E/CN.4/RES/2000/10.

${ }^{27}$ ibid.

${ }^{28}$ Including France, Germany, Italy, Poland, Sweden, Spain and the UK.
} 
on Adequate Housing (2000), ${ }^{29}$ Safe Drinking Water (2008), ${ }^{30}$ and Cultural Rights $(2009)^{31}$ did not require a vote for the initial resolutions that created them, signifying the level of acceptance for those mandates.

In contrast to the creation and renewal of ESCR mandates, resolutions on TGR mandates have shown significant divergence between the Global North and South and, indeed, occasionally between Global North States themselves. Special Procedures mandates have been a key vehicle for developing TGR but this has led those mandates to be framed in broad terms in order to enable mandate holders to assist with developing normative content. The broader the mandate, the less likely it is to be supported by Global North countries. ${ }^{32}$ All Global North States members of the CHR in $2000^{33}$ voted against the mandate on Foreign Debt, ${ }^{34}$ and have continued to call for a vote and then vote against the resolution each time the mandate has been renewed. The same has occurred in relation to International Solidarity $(2005)^{35}$ and its renewals, as well as Equitable and Democratic Order $(2011)^{36}$ and its renewal. Objections raised by Global North States, ranging from Ireland and Spain to the US and the UK, centre upon the vagueness of the mandates and whether they are appropriately placed within the human rights system and within a legal mechanism for protection and promotion. Similar issues were raised in terms of mandate on Toxic Waste $(1995)^{37}$ when all Global North States members of the $\mathrm{CHR}^{38}$ voted against its creation. However, subsequent renewals of the mandate passed without a vote, in part owing to the first mandate holder providing normative content to the mandate and demonstrating how and why it belongs within the human rights system. The 2012 mandate on a Clean Environment passed without a

\footnotetext{
${ }^{29}$ UNCHR Res 2000/9 'Special Rapporteur on Adequate Housing as a Component of the Right to an Adequate Standard of Living' (17 April 2009) UN Doc E/CN.4/RES/2000/9.

${ }^{30}$ UNHRC Res 7/22 'Human Rights and Access to Safe Drinking Water and Sanitation' (28 March 2008) UN Doc A/HRC/RES/7/22.

31 UNHRC Res 10/23 'Independent Expert in the Field of Cultural Rights' (26 March 2009) UN Doc A/HRC/RES/10/23.

${ }^{32}$ Freedman and Mchangama (n 2).

${ }^{33}$ Canada, Czech Republic, France, Germany, Italy, Norway, Poland, Spain, the UK and the US.

${ }^{34}$ UNCHR Res 2000/82 'Effects of Structural Adjustment Policies and Foreign Debt on the Full Enjoyment of All Human Rights, particularly Economic, Social and Cultural Rights' (26 April 2000) UN Doc E/CN.4/RES/2000/82.

35 UNCHR Res 2005/55 'Human Rights and International Solidarity' (20 April 2006) UN Doc E/CN.4/RES/2005/55.

${ }^{36}$ UNHRC Res 18/6 'Promotion of a Democratic and Equitable International Order' (29 September 2011) UN Doc A/HRC/RES/18/6.

37 UNCHR Res 1995/81 'Adverse Effects of the Illicit Movement and Dumping of Toxic and Dangerous Products and Wastes on the Enjoyment of Human Rights' (8 March 1995) UN Doc E/CN.4/RES/1995/81.

38 Australia, Austria, Canada, Finland, France, Germany, Hungary, Italy, Japan, the Netherlands, Poland, Republic of Korea, Romania, the UK and the US.
} 
$\operatorname{vote}^{39}$ and without any objection from Global North States member of the HRC, not least because the link between realisation of human rights and the environment has now been established. The mandate that caused divergence between Global North States, however, was on Human Rights and Transnational Corporations and Business ${ }^{40}(2005):^{41}$ on the one hand Australia, South Africa and the US voted against that mandate, on the other it was supported by other Global North States not only voting for its creation but some of whom sponsored the resolution. $^{42}$

In terms of vulnerable groups, Global North States have tended to vote in favour of resolutions creating these mandates, including on Discrimination Against Women in Law and Practice (2012), ${ }^{43}$ Human Rights Defenders (2000), ${ }^{44}$ Human Trafficking (2004), ${ }^{45}$ and Indigenous People. ${ }^{46}$ When thinking about States voting against vulnerable group mandates that will significantly impact national policies and laws, it is interesting to note, that China, Cuba and Rwanda all voted against the creation of the mandate on Human Rights Defenders. ${ }^{47}$ It is noteworthy that Global North States members of the $\mathrm{CHR}^{48}$ all voted against the creation of the mandate on people of African Descent (2002), ${ }^{49}$ with the exception of Japan which abstained. That mandate formed part of the drive to give effect to the Durban Declaration and Programme of Action $(2001)^{50}$ and which was politically contentious and divisive between the Global North and South, ${ }^{51}$ and of course the issue reparations for the transatlantic slave trade is one that threatened significant impact upon many Global North

\footnotetext{
${ }^{39}$ UNHRC Res 19/10 'Human Rights and the Environment' (19 April 2012) UN Doc A/HRC/RES/19/10.

${ }^{40}$ This can be considered to be TGR mandate because it brings into the human rights arena a subject a matter that impacts upon human rights rather than focusing on a specific right and because it addresses a subject matter that frequently impacts upon collectives or groups of victims. For more on the categorisation of TGR mandates see Freedman and Mchangama (n2) 172-173 and Appendix I.

${ }^{41}$ UNCHR Res 2005/69 'Human Rights and Transnational Corporations and Other Business Enterprises' (20 April 2005) UN Doc E/CN.4/RES/2005/69.

${ }_{42}$ Including Belgium, Czech Republic, Denmark, France, Germany, Greece, Norway, Poland, Spain and the $\mathrm{UK}$, not all of which were members of the CHR at that time.

${ }^{43}$ See (n 14)

${ }^{44}$ ibid.

45 ibid.

${ }^{46}$ ibid.

${ }^{47}$ ibid.

48 Austria, Belgium, Canada, Croatia, Czech Republic, France, Germany, Italy, Poland, Republic of Korea, Spain, Sweden and the UK.

${ }^{49}$ UNCHR Res 2002/68 'Racism, Racial Discrimination, Xenophobia and Related Intolerance' (25 April 2002) UN Doc E/CN.4/RES/2002/68.

50 'Report of the World Conference against Racism, Racial Discrimination, Xenophobia and Related Intolerance' World Conference against Racism, Racial Discrimination, Xenophobia and Related Intolerance (Durban 31 August-8 September 2001) (2001) UN Doc A/CONF.189/12.

${ }^{51}$ See eg C Camponovo, 'Disaster in Durban: The United Nations World Conference Against Racism, Racial Discrimination, Xenophobia, and Related Intolerance' (2003) 34 George Washington International Law Review 696.
} 
States. ${ }^{52}$ However, the vulnerable group mandate that most affects Global North States within their own territories is the one on Migrants. It is noteworthy that to date no Global North State has ratified the International Convention on the Protection of the Rights of All Migrant Workers and Members of Their Families (signed in 1990, entered into force 2003), ${ }^{53}$ yet not one such State voted against the creation of the mandate on that group in $1999 .{ }^{54}$ Indeed, EU States and the US sponsored the resolution creating the mandate on Migrants, and did so owing to key changes being made to the text of the originally-tabled draft resolution as those changes made the Convention less applicable to the types of migration that occurs into Global North States.

It is clear, therefore, that even when it comes to creating and renewing different types of Special Procedures mandates there is significant divergence between Global North and Global South States, and indeed divergence even between those countries from the Global North. Divergence of opinion relating to mandate creation or renewal are more likely to arise vis-à-vis TGR mandates, but also occur in relation to those that focus on specific categories of vulnerable groups that impact upon those countries' domestic policies. Indeed, no Global North States hold an ideological position that opposes non-CPR mandates as a matter of course. However, as we shall see, when non-CPR mandate holders visit and/or make recommendations about Global North States there have been far more instances of resistance than might be expected given the general support of those countries for the Special Procedures system.

\section{Global North States and resistance to scrutiny}

By and large Global North States appear to engage well with mandate holders: they allow a large number of visits from mandate holders and frequently can be relied upon to accept visit requests. ${ }^{55}$ That level of engagement remains superior to that of countries from the Global South, many of which reject or ignore such requests. ${ }^{56}$ However, as we will see below, there has been an increasing tendency on the part of some Global North States towards resisting mandate holders' reports and questioning the legitimacy of the visits and recommendations.

\footnotetext{
${ }^{52}$ See A Bayefsky, 'The UN World Conference Against Racism: A Racist Anti-Racism Conference' (2002) 96 American Society of International Law Proceedings 65, 71 citing resistance among European Union delegates to having to pay reparations for slavery.

${ }^{53}$ UNGA Res 45/158 'International Convention on the Protection of the Rights of All Migrant Workers and Members of Their Families' (18 December 1990) UN Doc A/RES/45/158.

${ }^{54}$ UNCHR Res 1999/44 'Human Rights of Migrants' (26 April 1999) UN Doc E/CN.4/RES/1999/44.

55 See OHCHR (n 4). The statistics provided by OHCHR also include the number of visit requests that have been ignored by States. For more on country visits, see Gaer's contribution to this volume.

${ }^{56} \mathrm{ibid}$.
} 
While the approach of such States is different from those of States that refuse to allow mandate holders to visit their territories insofar as they do not refuse or ignore mandate holders' visit requests, such responses are pernicious both for individual mandates and for the system as a whole. Moreover, these responses have not yet been explored or addressed extensively within the academy or by UN human rights bodies such as the Human Rights Council despite such occurrences becoming increasingly common.

One important factor to bear in mind when exploring these matters is that mandate holders generally request visits to States that present significant problems in relation to the thematic right. Therefore, we can posit that those Global North States most accepting of the need to protect and promote all types of rights through legal mechanisms are the least likely to be visited by mandate holders. In the context of ESCR, mandate holders have visited far more Global North States that resist the legal nature of those categories of rights than ones that support and implement those rights through legal mechanisms. ${ }^{57}$ That may be because countries that use legal mechanisms to uphold ESCR present fewer problems that require reports and recommendations, but of course this skews the data when examining the relationship between Global North States because mandate holders are more likely to visit Global North countries that present more problems in relation to ESCR and that will resist the reports and recommendations resulting from the visits.

ESCR, TGR and vulnerable group mandate holders appear to be critical of Global North States in ways that those countries push back against the most, frequently because those countries resist the legitimacy of their criticisms and recommendations. Of course there are some exceptions to that generalisation, for example when the US refused to allow unfettered access to Guantanamo Bay to four CPR mandate holders seeking to conduct a joint visit. ${ }^{58}$ However, the US, and Global North States generally, do not question the legitimacy of legal mechanisms to protect and promote CPR, but tensions seem to arise where those countries consider matters to fall under 'security' rather than 'human rights' umbrella. ${ }^{59}$

\footnotetext{
57 See <www.ohchr.org/EN/HRBodies/SP/Pages/countryvisitsa-e.aspx> listing the country visits undertaken since 1998. It is interesting to note the relatively few ESCR and TGR visits to Ireland, Portugal and Spain countries that accord greater legal protection to ESCR - compared with those undertaken to Canada, the UK and the US.

${ }^{58}$ ECOSOC 'Situation of Detainees at Guantánamo Bay’ (27 February 2006) UN Doc E/CN.4/2006/120.

${ }^{59}$ It is important to note that some of the most prominent examples of when Global North States have sought to restrict mandate holders' unfettered access relate to security vs human rights debates. Much has been written about how Global North States approach the security agenda and human rights: see eg F Crépeau, D Nakache and I Atak, 'International Migration: Security Concerns and Human Rights Standards' (2007) 44 Transcultural Psychiatry 311; BJ Goold and L Lazarus (eds), Security and Human Rights (Hart 2007); B Buzan and O Waever, 'Macrosecuritization and Security Constellations: Reconsidering Scale in Securitization Theory' (2009) 35 Review of International Studies 253; E Guild, Security and Migration in the 21st Century (Polity 2009).
} 
Resistance to mandate holders' activities relating to issues that Global North States consider security concerns - ranging from the 'War on Terror' to irregular migration - appear to underpin most instances where a Global North State fails fully to engage with a CPR mandate holder.

Global North States have adopted a similar approach to mandate holders on vulnerable groups as they have towards those on CPR. Generally, countries allow those mandate holders unfettered access to conduct fact-finding and are responsive and receptive to reports and recommendations. However, where they view the vulnerable group mandate as examining security concerns rather than human rights, there appears to be greater resistance both to the mandate holder's visit and the report. The clearest example is the mandate on Migrants, with Australia refusing to provide assurances to the mandate holder that persons communicating with him regarding the treatment of detained foreigners would not be subjected to the possibilities of prosecution provided for in the Border Force Act of $2015 .{ }^{60}$ That refusal was contrary to the 1999 terms of reference for fact-finding missions by Special Rapporteurs and the Human Rights Council Resolution on cooperation with the United Nations, its representatives and mechanisms in the field of human rights. ${ }^{61}$ But even when a country supports a mandate on a vulnerable group it may resist mandate holders reporting on issues that it considers 'security concerns', as occurred when the mandate holder on Violence Against Women was refused full access to female irregular migrants in a UK detention centre. $^{62}$

Resistance to ESCR and TGR mandates when it occurs appears to stem not from the security versus human rights debate, but rather from an unwillingness to engage with the plausibility that such rights exist as legal rights or that, if they do, they are being violated by government policies.

To illustrate ways in which this resistance manifests itself, we shall examine three case studies: (1) UK and housing; (2) Canada and food; and (3) the EU and migrants. In all three instances the mandate holders were looking at human rights concerns that impact upon politics and government policies relating to social protection. All of those mandates require

\footnotetext{
${ }^{60}$ B Doherty, 'Australia up for human rights council seat despite UN official's criticism of asylum secrecy' The Guardian (London, 26 September 2015) <www.theguardian.com/law/2015/sep/26/australia-up-for-humanrights-council-seat-despite-senior-un-officials-criticism> accessed 3 April 2016.

${ }^{61}$ UNHRC Res 12/2 'Cooperation with the United Nations, its Representatives and Mechanisms in the Field of Human Rights' (1 October 2009) UN Doc A/HRC/RES/12/2.

${ }^{62}$ M Townsend, 'Yarl's Wood: UN special rapporteur to censure UK government' The Guardian (London, 3 January 2011 <www.theguardian.com/uk-news/2015/jan/03/yarls-wood-un-special-rapporteur-censure> accessed 3 April 2016. Note that the UK resistance to this mandated holder was despite its support of the creation of the mandate on Violence Against Women.
} 
the mandate holders to question whether States had discharged their duties or whether they had violated the rights with which the mandates are concerned. The policies with which they are concerned are ones that are integral to domestic politics and that resonate with voters, namely housing and benefits, food security and the rights of migrants (as a vulnerable group). One common factor that underscores that point is that, as we will see below, the responses seem to have been aimed at the voters reading or watching the media rather than at the international human rights community. Indeed, as will become evident, many of those responses fail to engage adequately or at all with the substance of the mandate holders' reports, or the human rights concerns raised by those experts, but rather seek to undermine the legitimacy of their visits or their credentials.

\section{A. UK and housing}

In 2013 the UN Special Rapporteur on Adequate Housing as a Component of the Right to an Adequate Standard of Living, and on the Right to Non-Discrimination in this Context, ${ }^{63}$ Raquel Rolnik, visited the UK and as part of her findings and recommendations on a range of issues she commented on the spare-room subsidy ${ }^{64}$ and criticised the UK for human rights violations. ${ }^{65}$ She commented on the Coalition Government's policy to charge council house tenants for supposedly under-occupying homes based on numbers of residents and bedrooms. ${ }^{66}$ Rolnik claimed that the policy could violate the right to adequate housing, not least owing to the shortage of one and two bedroom council housing. She also noted that the subsidy may impact the realisation of other rights, particularly where people were forced to choose between housing, food and heating. ${ }^{67}$

It is important to understand why Rolnik undertook a visit to the UK and why she focussed on the Government's 'spare room subsidy' policy. Rolnik is a Brazilian urban

\footnotetext{
${ }^{63}$ UNCHR Res 2000/9 'Question of the Realization in all countries of the Economic, Social and Cultural Rights contained in the Universal Declaration of Human Rights and in the International Covenant on Economic, Social and Cultural Rights, and Study of Special Problems which the Developing Countries face in their Efforts to achieve these Human Rights' (17 April 2000) UN Doc E/CN.4/RES/2000/9; adopted by the HRC in UNHRC Res 6/27 'Adequate Housing as a Component of the Right to an Adequate Standard of Living' (14 December 2007) UN Doc A/HRC/RES/6/27; and extended in 2010 (UNHRC Res 15/8 (6 October 2010) UN Doc A/HRC/RES/15/8) and 2014 (UNHRC Res 25/17 (14 April 2014) UN Doc A/HRC/RES/25/17).

${ }^{64}$ Department for Work and Pensions, 'Local authorities and advisers: removal of the spare room subsidy' 1 March 2013 <www.gov.uk/government/collections/local-authorities-removal-of-the-spare-room-subsidy> accessed 3 April 2016.

${ }^{65}$ UNHRC 'Mission to the United Kingdom of Great Britain and Northern Ireland' (30 December 2013) UN Doc A/HRC/25/54/Add.2, paras 46-53.

${ }^{66}$ ibid paras 46-48. See generally H Siddique, 'Bedroom tax: the housing benefit reform explained', The Guardian (London, 17 July 2014) <www.theguardian.com/society/2014/jul/17/bedroom-tax-housing-benefitreform-explained $>$ accessed 3 April 2016.

67 'Mission to the United Kingdom of Great Britain and Northern Ireland' (n 65), para 49.
} 
planner and architect who brought her professional experience to bear not only on the substance of her reports but also in the range of audiences that she addressed. ${ }^{68}$ Rolnik's tenure began in 2008 and finished in 2014, thus beginning at the time of the global financial crisis. That event was a central theme in Rolnik's work as a mandate holder: she focussed two of her reports on the impact on housing of the global financial crisis and related issues, ${ }^{69}$ as well as undertaking related missions to the World Bank. ${ }^{70}$ As Hohmann states, these aspects of Rolnik's work emphasised her 'demands to imagine housing and land within a fundamentally different paradigm: as social and public goods, not as financial instruments or commodified market assets'. ${ }^{71}$ Throughout her time as Special Rapporteur, Rolnik focussed on States and governments' role in the right to adequate housing, particularly in relation to policies and interventions, as well as the use of housing as a financial asset. Indeed, her first report detailed the "fundamental flaws in current economic and housing policies ${ }^{, 72}$ and the 'inability of market mechanisms to provide adequate and affordable housing for all ${ }^{173}$ and the discriminatory aspect of neo-liberal housing policies. ${ }^{74}$

The Special Rapporteur used a human rights lens to view the UK spare room subsidy, as per the terms of her mandate. Although she undertook significant fact-finding, the information that she shared and her recommendations did not cover ground that had not already been discussed in the UK media ${ }^{75}$ (although her rights-based stance was a new aspect that added to the debate). Indeed, her comments and recommendations were far less critical than some elements of the UK press and civil society previously had been about the policy. But Rolnik's comments hit a raw nerve with the Government. Grant Shapps, the

\footnotetext{
${ }^{68}$ See Hohmann's chapter in this collection.

${ }^{69}$ UNHRC 'Report of the Special Rapporteur on Adequate Housing as a Component of the Right to an Adequate Standard of Living, and on the Right to Non-Discrimination in this Context, Raquel Rolnik' (4 February 2009) UN Doc A/HRC/10/7; UNHRC 'Special Rapporteur on Adequate Housing as a Component of the Right to an Adequate Standard of Living' (10 August 2012) UN Doc A/67/286.

${ }^{70}$ UNHRC 'Report of the Special Rapporteur on Adequate Housing as a Component of the Right to an Adequate Standard of Living, and on the Right to Non-Discrimination in this Context, Raquel Rolnik Addendum Mission to the World Bank' (3 February 2013) UN Doc A/HRC/22/46/Add.3, paras 57-69.

${ }^{71}$ See Hohmann's chapter in this collection.

${ }^{72} \mathrm{UN}$ Doc A/HRC/10/7 (n 69), para 18.

${ }^{73}$ ibid.

${ }^{74}$ See Hohmann's chapter in this collection.

${ }^{75}$ See eg F Ryan, 'Bedroom tax: Pushing those "getting by" over the edge' New Statesman (London, 13 March 2013) <www.newStatesman.com/voices/2013/03/bedroom-tax-pushing-those-getting-by-over-the-edge> accessed 3 April 2016; Liberty, 'Bedroom tax breaches right to family life' (Liberty, 21 March 2013) <www.liberty-human-rights.org.uk/news/press-releases/liberty-bedroom-tax-breaches-right-family-life> accessed 3 April 2016; Huffington Post UK, 'Disability Rights: Bedroom Tax Illegally Discriminates Against Disabled People Court Hears' (Huffington Post, 15 May 2013) <www.huffingtonpost.co.uk/2013/05/15/bedroom-tax-illegal-human-rights-disability-_n_3280442.html> accessed3 April 2016; P Wintour, 'Bedroom tax affected more than 522,000 people, first figures show' The Guardian (London, 13 November 2013) <www.theguardian.com/society/2013/nov/13/bedroom-tax-figuresaugust> accessed 3 April 2016.
} 
Conservative Party Chairman, sent a letter of complaint to the United Nations, demanding an apology and an explanation for her comments. ${ }^{76} \mathrm{He}$ accused Rolnik of bias and political motives. ${ }^{77}$ He questioned why she had visited the UK rather than focussing her efforts on graver situations elsewhere in the world. ${ }^{78}$ Furthermore, he accused her of conducting her fact-finding mission without permission. ${ }^{79}$ That reaction was followed by personal attacks from other Government officials - for example, Conservative Party Member of Parliament, Stuart Jackson, called Rolnik a 'Loopy Brazilian Leftie' ${ }^{80}$ - and from centre-right elements of the media.

Mandate holders are not allowed to visit a country without prior permission; and even though the UK has issued a standing invitation to all Special Procedures mandate holders, if one wants to visit s/he must liaise with the government before undertaking a mission to that country. Rolnik's visit to the UK, then, was not an intrusion but was a carefully planned and coordinated visit to which the UK Government had consented and helped organise. Her focus on the spare room subsidy was in line with her thematic interests, reports and recommendations throughout her mandate. And the question of whether ESCR bind governments in terms of their policies is one that has long-been answered in the affirmative ${ }^{81}$ in the doctrine and the case law, despite the resistance of States.

Those initial responses occurred immediately after Rolnik's visit: so perhaps Shapps was badly briefed or perhaps not briefed at all regarding Rolnik's visit and Special Procedures more generally. But those attacks, personal and professional, recurred when Rolnik presented her report to the Human Rights Council in February 2014 and at that point Government officials could no longer claim to have been unaware of how and why the visit

\footnotetext{
76 See eg BBC News, 'Conservatives protest to UN over "bedroom tax" report' (BBC News Online, 11 September 2013) <www.bbc.co.uk/news/uk-politics-24046094> accessed 3 April 2016.

${ }^{77}$ See eg BBC News, 'Grant Shapps: UN “bedroom tax” report is a disgrace' (BBC News Online, 11 September 2013) <www.bbc.co.uk/news/uk-politics-24044597> accessed 3 April 2016.

${ }^{78}$ For the full text of the letter, see M Wallace, 'Grant Shapps writes to the UN Secretary-General in protest at biased Housing investigator' (Conservative Home, 12 September 2013) <www.conservativehome.com/parliament/2013/09/grant-shapps-writes-to-the-un-secretary-general-in-protestat-biased-housing-investigator.html> accessed 3 April 2016.

${ }^{79}$ Cf A Nolan, 'Grant Shapps should reconsider his ill-informed UN "bedroom tax" outrage' The Guardian (London, 13 September 2013) <www.theguardian.com/commentisfree/2013/sep/13/grant-shapps-un-bedroomtax-outrage> accessed 3 April 2016.

${ }^{80}$ Channel 4 News, 'Bedroom tax row: Grant Shapps v "woman from Brazil"' (Channel 4 News Online, 11 September 2013) <www.channel4.com/news/bedroom-tax-un-grant-shapps-brazil-row> accessed 3 April 2016.

${ }^{81}$ See eg UNCESCR, General Comment No 20 'Non-discrimination in Economic, Social and Cultural Rights' (2 July 2009) UN Doc E/C12/GC20; UN Committee on the Rights of the Child (CRC), General Comment No 5 'General Measures of Implementation of the Convention on the Rights of the Child (27 November 2003) UN Doc CRC/GC/2003/5; P Hunt et al, 'Implementation of Economic, Social and Cultural Rights' in N Rodley and E Sheeran (eds), Routledge Handbook of International Human Rights Law (Routledge 2013).
} 
took place. ${ }^{82}$ Although the UK's delegates to the Human Rights Council in Geneva adopted a respectful, albeit critical, stance towards Rolnik's report in the interactive dialogue following her presentation, the UK Government continued to attack Rolnik at home. Kris Hopkins, who was the Conservative Party's Housing Minister at that time, dismissed Rolnik's report as a 'Marxist diatribe', ${ }^{83}$ a comment that fed directly into the ongoing political discussions at that time surrounding the austerity agenda and the 'welfare reform' at the heart of the Government's programme. The response of the Conservative Party, which drove those agendas within the Coalition Government, demonstrated the level to which Rolnik's report and recommendations hit home with 'uncomfortable truths' about its policies on welfare and how the reaction to her report was instrumentalised to mobilise the electorate. ${ }^{84}$

\section{B. Canada and food}

In 2012 the UN Special Rapporteur on the Right to Food, Olivier De Schutter, visited Canada $^{85}$ and in particular focussed on access to healthy food and on food security for the poor and for vulnerable or minority groups. His report and recommendations emphasised, amongst others, the increasing financial and developmental inequality in Canada ${ }^{86}$ and the resulting impact upon the right to food. ${ }^{87}$ De Schutter focussed on social policies, particularly social assistance benefits and the minimum wage, as well as the rising costs of basic necessities, including food, when addressing issues of accessibility, availability and affordability and quality of food within the country. His report criticised government policies and inaction to combat poor nutrition that manifests in malnutrition, obesity, and lack of food security particularly in relation to healthy food. ${ }^{88}$ In particular, he focussed upon the right to

\footnotetext{
${ }^{82}$ For the UK official response to Rolnik's report, see UNHRC 'Mission to the United Kingdom of Great Britain and Northern Ireland: Comments by the State on the report of the Special Rapporteur' (5 March 2014) UN Doc A/HRC/25/54/Add.4.

83 BBC News, 'Ministers criticise "partisan" UN housing report' (BBC News Online, 3 February 2014) <www.bbc.co.uk/news/uk-politics-26026021> accessed 3 April 2016.

${ }^{84}$ For a nuanced and in-depth assessment of the responses to Rolnik's report, see P Butler, 'Bedroom tax: Raquel Rolnik's uncomfortable truths' The Guardian (London, 3 February 2014) $<$ www.theguardian.com/society/patrick-butler-cuts-blog/2014/feb/03/bedroom-tax-raquel-rolnik-uncomfortablehousing-truths> accessed 3 April 2016.

${ }^{85}$ The mission took place 6-16 May 2012. See, UNHRC, 'Report of the Special Rapporteur on the Right to Food, Olivier de Schutter: Addendum, Mission to Canada' (24 December 2012) UN Doc A/HRC/22/50/Add.1.

${ }^{86}$ ibid, paras 5 and 6.

${ }^{87}$ ibid, paras $7-8$.

${ }^{88}$ ibid, paras 41-47.
} 
food and indigenous populations, ${ }^{89}$ which was a particular point of contention for Canada given its domestic record in terms of treatment of those populations. ${ }^{90}$

De Schutter was appointed as mandate holder in 2008 and his tenure ran until 2014. Throughout his tenure, de Schutter focussed on the need for diverse, culturally-acceptable foods, supporting local food production, sustaining soil and water resources, and raising food security rather than 'the one-dimensional quest to produce more food'. ${ }^{91}$ His final annual report focussed on local and national strategies for food security, the availability of nutritious food rather than calorie consumption and sustainable production and consumption, ${ }^{92}$ demonstrating his key interests in those themes during his tenure. In particular, and in keeping with his work as mandate holder, de Schutter sought to situate the right to food within a broader framework of poverty reduction, development and broader financial security. ${ }^{93}$ De Schutter conducted visits to countries from the Global South and Global North, including Benin, Brazil, Cameroon, China, Guatemala, Nicaragua, Mexico, South Africa, Syria, as well as to institutions such as the World Trade Organisation. The mission to Canada was his first to a Global North State but the themes that he focussed upon were ones that had roots in his previous country-specific and annual reports as well as in his previous scholarship. It is important to understand that de Schutter, a legal scholar specialising in economic and social rights, used his tenure as mandate holder to develop the way that the right to food is understood and to situate it within the broader economic, social and cultural contexts.

When de Schutter visited and reported on Canada, he emphasised issues relating to food policies, the adequacy and accessibility of food and issues relating to development and sustainability. ${ }^{94} \mathrm{He}$ focussed in particular on indigenous populations, and on the issue of malnutrition, obesity and poverty. ${ }^{95}$ Those thematic issues were in line with his previous annual and country-specific reports throughout his tenure. He also highlighted the

\footnotetext{
${ }^{89}$ ibid, paras 53-68.

${ }^{90}$ For more on the human rights of indigenous populations in Canada see $\mathrm{P}$ Thornberry, Indigenous Peoples and Human Rights (Manchester University Press, 2002), which cites and analyses different UN bodies' jurisprudence. For more on the disparity between indigenous people and other Canadians in relation to health see M Cooke, F Mitrou, D Lawrence, E Guimond and D Beavon, 'Indigenous well-being in four countries: an application of the UNDP's human development index to Indigenous peoples in Australia, Canada, New Zealand, and the United States' (2007) 7 BMC International Health and Human Rights 1, 1-11.

${ }^{91}$ UNHRC 'Report of the Special Rapporteur on the Right to Food, Olivier De Schutter, Final Report: The Transformative Potential of the Right to Food' (24 January 2014) UN Doc A/HRC/25/57.

${ }^{92}$ ibid.

93 ibid para 50.

${ }^{94}$ OHCHR, 'Olivier De Schutter, Special Rapporteur on the right to food: Visit to Canada from 6 to 16 May 2012 - $\quad$ Preliminary Remarks' $\quad$ (OHCHR, $16 \quad$ May 2012$)$ <www.srfood.org/images/stories/pdf/officialreports/201205_canadaprelim_en.pdf> accessed 3 April 2016. ${ }^{95}$ ibid.
} 
weaknesses in Canada's legal framework for ESCR generally, ${ }^{96}$ contrasting those deficiencies with the country's 'impressive' record on $\mathrm{CPR} .{ }^{97}$

De Schutter's report and his recommendations were poorly-received by Canada's government, and in particular the Government resisted the idea that legal mechanisms are able to investigate and uphold ESCR generally and the right to food specifically within its territory. The reaction from Canada's Government challenged the legitimacy of the visit, the report and the mandate holder. Systematically calling the Special Rapporteur the 'UN hunger specialist' and questioning the purpose of the visit by claiming that 'there's no hunger in Canada', ${ }^{98}$ Immigration Minister Jason Kenney stated: 'It would be our hope that the contributions we make to the United Nations are used to help starving people in developing countries, not to give lectures to wealthy and developed countries like Canada. And I think this is a discredit to the United Nations'. ${ }^{99}$ Health Minister Leona Aglukkaq called de Schutter 'ill-informed' and 'patronising, ${ }^{100}$ alleging that the mandate holder had failed adequately to engage with or understand indigenous populations during his visit.

Those reactions demonstrate failures to engage with the substance of the report. The Government Ministers focussed their remarks on de Schutter rather than on the recommendations that he proposed. Indeed, it appears that Minister Kenney in particular was aiming his remarks towards the Canadian public, using the Special Rapporteur as a political ploy rather than treating him as an interlocutor. More than 130 organisations and 400 individuals signed a letter written by Amnesty Canada to then Prime Minister Stephen Harper, expressing deep concern about the 'unprecedented attacks on [de Schutter's] integrity and professionalism' in the House of Commons and in the media. ${ }^{101}$ The letter noted that Government ministers had treated other mandate holders in a similar manner in previous months, including attacks on James Anaya, the UN Special Rapporteur on the Rights of Indigenous Peoples in December 2011. ${ }^{102}$

\footnotetext{
${ }^{96}$ De Schutter (n 94) paras 9-12.

97 ibid, para 9.

98 L Whittington, 'UN food envoy blasts inequality, poverty in Canada' (The Star, 16 May 2012) www.thestar.com/news/canada/2012/05/16/un_food_envoy_blasts_inequality_poverty_in_canada.html accessed 3 April 2016.

${ }^{99}$ ibid.

${ }^{100}$ H Scoffield, 'Olivier De Schutter, UN Food Envoy, Provokes Ottawa with Findings on Hunger and Poor Diet in Canada' (Huffington Post, 16 May 2012) <www.huffingtonpost.ca/2012/05/16/olivier-de-schutter-un-foodenvoy-canada_n_1521324.html> accessed 3 April 2016.

101 Amnesty International (+ 139 Organisations), 'Letter to Prime Minister Stephen Harper' (Amnesty International, 30 May 2012) < www.amnesty.ca/sites/amnesty/files/canadaletterpmonsr30may12.pdf> accessed 3 April 2016.

102 ibid.
} 
When criticised, de Schutter responded that 'his role is to help countries identify blind spots in public policies that would be easier to ignore - and that he didn't see why he should mince his words'. ${ }^{103} \mathrm{He}$ emphasised that most of his visits are to developing countries, but he insisted that there remains a need to report on the wealthiest States and pointed to the 'desperate situation' of the poorest in Canada including one million First Nations people and 55,000 Inuit. ${ }^{104}$ Yet, despite de Schutter's response and those of human rights actors, Canada's government continued to question the legitimacy of the mandate holder and of the country-visit and report.

In March 2013 de Schutter presented his report to the Human Rights Council and during the interactive dialogue that ensued Canada again criticised 'the approach which the Special Rapporteur had taken in an attempt to assess Canadian laws' arguing that he had exceeded his mandate by focusing on issues such as indigenous peoples. ${ }^{105}$ Sandeep Prasad, Executive Director of Action Canada for Population and Development, observed that 'the Canadian government continued its pattern of defensiveness towards legitimate human rights scrutiny by UN mechanisms instead of making a clear commitment to serious consideration and implementation of those recommendations'. ${ }^{106}$

\section{EU and migrants}

The mandate of the Special Rapporteur on the Human Rights of Migrants was created in $1999^{107}$ and continues to operate 14 years later. Francois Crépeau's tenure as mandate holder began in 2011 and will finish in 2017. He is a legal scholar who specialises in migration control mechanisms, the rights of foreigners, the interfaces between security and migration, and between the Rule of Law and globalisation. Those are themes that have been central in his reports and activities as mandate holder. ${ }^{108}$ His tenure is taking place during the time

\footnotetext{
103 L Payton, 'UN official sparks debate over Canadian food security' (CBC News, 16 May 2012) <www.cbc.ca/news/politics/un-official-sparks-debate-over-canadian-food-security-1.1130281> accessed 3 April 2016.

104 ibid.

${ }^{105}$ OHCHR, 'Human Rights Council holds Interactive dialogue with Experts on the Right to Food and the Right to Adequate Housing' $\quad$ (OHCHR, 4013 <www.ohchr.org/en/NewsEvents/Pages/DisplayNews.aspx?NewsID=13071\&LangID=E> accessed 3 April 2016.

${ }^{106}$ Amnesty International, 'Canada - UN Special Rapporteur on the right to food presents his report' (Amnesty International, 4 March 2013) <www.amnesty.ca/news/news-releases/canada-un-special-rapporteur-on-the-rightto-food-presents-his-report> accessed 3 April 2016.

${ }^{107}$ UNCHR Res 1999/44 'Human Rights of Migrants' (27 April 1999) UN Doc E/CN.4/RES/1999/44.

108 OHCHR, 'Annual Reports of the Special Rapporteur on the Human Rights of Migrants' <www.ohchr.org/EN/Issues/Migration/SRMigrants/Pages/AnnualReports.aspx> accessed 3 April 2016.
} 
when migration to Europe, via boats from North Africa and the Middle East, grew exponentially and as such he focussed upon that growing and worsening humanitarian crisis.

Crépeau, in his capacity as the United Nations Special Rapporteur on the Human Rights of Migrants, spent his first year as mandate holder visiting Albania, Greece, ${ }^{109}$ Italy, ${ }^{110}$ Tunisia $^{111}$ and Turkey. ${ }^{112} \mathrm{He}$ was particularly concerned to find out about and provide recommendations on the points of departure and arrival for irregular migrants seeking to enter Europe. He presented his first report on European border policies to the UN Human Rights Council in June 2013. ${ }^{113}$ Having spent a year investigating the rights of migrants in that region, Crépeau offered a range of recommendations. Criticising the focus on security concerns, he called for the EU and its Member States to adopt a human rights-based approach to migration. ${ }^{114}$

At the interactive dialogue at the Human Rights Council, during which the mandate holder publicly presents his or her report and receives questions and comments from States members or observers at the body, country after country from across the world repeated the fundamental necessity of a human rights-based approach to migration. ${ }^{115}$ However, EU countries all but failed to engage with the Special Rapporteur during those discussions. Portugal and Montenegro did mention his report but ignored the main thrust of his arguments. Greece and Italy, which had been visited by Crépeau when he was investigating the EU's external borders, welcomed the analysis that showed how it was impossible for them to guard the external borders of the EU on their own, but sought to downplay the egregious violations of migrants' rights, including detention without charge and lack of access to legal services and healthcare. All other EU Member States studiously avoided mentioning Crépeau's report. $^{116}$

\footnotetext{
${ }^{109}$ UNHRC 'Report of the Special Rapporteur on the Human Rights of Migrants, François Crépeau: Addendum, Mission to Greece' (17 April 2013) UN Doc A/HRC/23/46/Add.4.

${ }^{110}$ UNHRC 'Report of the Special Rapporteur on the Human Rights of Migrants, François Crépeau: Addendum, Mission to Italy' (30 April 2013) UN Doc A/HRC/23/46/Add.3.

${ }^{111}$ UNHRC 'Report of the Special Rapporteur on the Human Rights of Migrants, François Crépeau: Addendum, Mission to Tunisia' (3 May 2013) UN Doc A/HRC/23/46/Add.1.

${ }^{112}$ UNHRC 'Report of the Special Rapporteur on the Human rights of Migrants, François Crépeau: Addendum, Mission to Turkey' (17 April 2013) UN Doc A/HRC/23/46/Add.2.

${ }^{113}$ UNHRC 'Report of the Special Rapporteur on the Human Rights of Migrants, François Crépeau: Regional Study: Management of the External Borders of the European Union and its Impact on the Human Rights of Migrants' (24 April 2013) UN Doc A/HRC/23/46.

${ }^{114}$ ibid.

${ }^{115}$ OHCHR 'Human Rights Council concludes Dialogue with Special Rapporteurs on the Right to Health and $\begin{array}{lllllll}\text { the Rights } & \text { of } & \text { Migrants' } & \text { (OHCHR, } & 28 & \text { May } & \text { 2013) }\end{array}$ <www.ohchr.org/EN/NewsEvents/Pages/DisplayNews.aspx?NewsID=13365\&LangID=E> accessed 3 April 2016.

116 ibid.
} 
Only the EU as an institution provided a considered response, accepting a number of recommendations. ${ }^{117}$ However, in this very sensitive field, States still have the final political word, in particular through the role of the European Council, and the response of the EU reflected the divisions among European States and the little leeway that the European institutions in Brussels have.

At the express request of the Human Rights Council following the migration tragedies in the Mediterranean during the summer of 2014, a follow-up report was presented in June 2015. ${ }^{118}$ This report emphasised that European States should organise mobility rather than resist it, as repression of irregular migration only increases the precariousness of the migrants and therefore entrenches the power of smuggling rings and unscrupulous employers. It highlighted the futility of 'fighting the smugglers' as long as there would be a market for mobility services across borders and this market was not operated by the States themselves: the paradox is that States have lost the control of the border by insisting on the closure of the border. ${ }^{119}$ This was not a message that most European politicians were ready to hear or adopt, as, on their domestic political stage, they were generally expected to deliver a strong antiimmigration message, emphasising territorial sovereignty, border closures and repression. The interactive dialogue at the Human Rights Council again reflected those States' dismissal of Crépeau's recommendations. ${ }^{120}$

\section{Observations}

Based on the analysis of the three case studies, the resounding message from these reactions is that the Global North States in question either thought that the mandate holders were interfering with domestic political matters or were concerned about why they have received visits when the experts could have gone to other countries with (in their view) far more acute problems. Rather than engaging with or addressing mandate holders' concerns, governments choose either to react negatively or to avoid discussing the criticisms raised in the reports.

\footnotetext{
${ }^{117}$ UNHRC 'Note Verbale dated 21 May 2013 from the Permanent Delegation of the European Union to the United Nations Office and other international organizations in Geneva addressed to the Office of the United Nations High Commissioner for Human Rights' (24 May 2013) UN Doc A/HRC/23/G/2.

${ }^{118}$ UNHRC 'Report of the Special Rapporteur on the Human Rights of Migrants, François Crépeau: Banking on Mobility over a Generation: Follow-up to the Regional Study on the Management of the External Borders of the European Union and its Impact on the Human Rights of Migrants' (8 May 2015) UN Doc A/HRC/29/36.

119 ibid, paras 24-84.

${ }^{120}$ OHCHR 'Human Rights Council holds enhanced interactive dialogue on the human rights of migrants' (OHCHR

15 June 2015) <www.ohchr.org/EN/NewsEvents/Pages/DisplayNews.aspx?NewsID=16079\&LangID=E> accessed 3 April 2016.
} 
Those responses to Special Procedures mandate holders may be compared with Global North States' engagement with other international human rights actors - for instance, UN treaty bodies. ${ }^{121}$ While some countries submit their reports late, ${ }^{122}$ ignore interim measures $^{123}$ or fail to implement the quasi-judicial rulings from those bodies, the governments do not attack the institutions or the individual experts that sit on them.

The question, then, must be why some Global North States respond to Special Procedures in a manner that does not occur in relation to other international human rights actors. One significant factor may be the nature of the mechanisms. Global North States seem to respond better, or at least more respectfully, towards judicial and quasi-judicial bodies than to Special Procedures whose mandates are broader than judicial functions. Secondly, some Global North States seemingly respond better to mechanisms to which they have consented through ratification of treaties than to Special Procedures which, despite visit requests needing to be accepted, are able to discuss publicly discuss publicly any country's human rights record, with or without its consent. ${ }^{124}$ Thirdly, some Global North States seem to prefer when reports are produced by institutions (such as treaty bodies or international judicial mechanisms), where geographical composition is 'balanced' and language is checked, rather than by individual experts whose behaviour may be less predictable and the language used in their reports may be of a more personal format. Fourthly, the very public pronouncements of mandate holders' findings in press conferences at the conclusion of a visit is markedly different to the formal reporting of judicial and quasi-judicial rulings, and the information is reported far more widely in the domestic media - a fact that can be expected to affect the reaction of the States visited. Those four factors in turn are important when turning to explore possible motivations behind those reactions and the impact that they have on the Special Procedures system.

\footnotetext{
${ }^{121}$ See eg UN High Commissioner for Human Rights 'Strengthening the United Nations Human Rights Treaty Body System' (26 June 2012) UN Doc A/66/860, setting out States' responses to treaty bodies generally. More broadly regarding the need for reform to the treaty bodies and State responses to that process, see C Broecker and M O'Flaherty, 'The Outcome of the General Assembly's Treaty Body Strengthening Process: An Important Milestone on a Longer Journey' (Universal Rights Group 2014) <www.universal-rights.org/wpcontent/uploads/2015/02/URG_Policy_Brief_web_pge_by_pge_hd.pdf> accessed 3 April 2016.

${ }_{122}$ See eg A Bayefsy, The UN Human Rights Treaty System: Universality at the Crossroads (Transnational Publishers, 2001) <www.bayefsky.com/report/finalreport.pdf> accessed 3 April 2016, setting out the status of State reporting and responses to communications.

${ }^{123}$ There are many examples of this, although the most widely referenced of course is the US failure to uphold interim measures issued in relation to death penalty cases.

${ }^{124}$ There are many articles that discuss state engagement with and the impact of treaty bodies using different methodologies such as submission of periodic reports or responses to concluding observations. Some noteworthy examples include: A Bayefsky (n 122); P Alston and J Crawford (eds), The Future of Human Rights Treaty Monitoring (CUP, 2000); and C Heyns and F Viljoen, 'The impact of the United Nations human rights treaties on the domestic level' (2001) 23 Human Rights Quarterly, 483-535.
} 


\section{Global North motivations}

The difference is stark between what Global North governments say about human rights across the world and how they respond to reports about their own records. While some resistance to any criticism is to be expected, the responses detailed in the preceding section illustrate that some Global North countries' reactions to some ESCR and vulnerable group mandates seek to undermine the credibility of individual mandate holders. In turn this can be expected to impact on the system more broadly. Where it comes to human rights elsewhere, including ESCR and vulnerable groups, those governments adopt an expansive position that such rights are good things and that all persons ought to have them implemented and realised. This is evidenced by those governments having voted in favour of the mandates that then criticise them and by those governments - at the Human Rights Council - encouraging other countries to respond to visit requests and communications from those mandate holders. When it comes to their own domestic records, those issues become political and involve domestic discussions with voters.

In our view, there are two key reasons for this disparity and for how those States respond to mandate holders' reports. First, when a report criticises how government policies affect human rights the reaction of the Global North States discussed in the case studies above suggest that such States typically view this as interference with domestic concerns and react in a way that is speaking to the electorate rather than to the mandate holders. Secondly, those States look at egregious abuses elsewhere and question why they are being visited and criticised, pointing to worse abuses elsewhere - a reaction that occurs owing to Global North countries seeing themselves as 'being the good guys', placed on a human rights pedestal. ${ }^{125}$

A structural feature of electoral democracies is that politicians react to political incentive, and therefore focus on what they perceive is the desire of their electorate: their political survival is at stake Therefore, where there is a conflict between a populist discourse and a legal human rights obligation, politicians are likely to speak to the populist stance or, at best, to remain silent, rather than damage their relationship with the electorate and risk their political future.

Moreover, in the past 20 years, despite progress in human rights doctrine and case law, one can observe an increasing resistance towards the independent oversight mechanisms which were established in the preceding era. We have seen very populist reactions when

\footnotetext{
${ }^{125}$ See R Freedman, Failing to Protect: The United Nations and the Politicisation of Human Rights (OUP/Hurst 2014) 119-26.
} 
courts, tribunals, environmental impact assessment mechanisms, human rights commissions or ombudspersons have criticised the measures taken by governments, especially in the security and anti-terrorism fields.

When it comes to human rights issues and international law, especially as it relates to the current security agenda (and much has been 'securitised' in government policies: antiterrorism laws are now applied to environmental groups protesting the construction of infrastructures such as pipelines), politicians are increasingly becoming involved from the outset and being dismissive of the few independent and expert bodies that remain within the international arena. This makes it even more difficult than previously to get States to engage in discussions about abuses within their jurisdiction.

Politicians frequently resort to 'speech acts' when there is no easy way to measure the results of their actions. The most common speech act is changing the law. If a problem arises, the relevant minister will announce a change in the law. The fact that there is precious little way to measure the impact of the change is arguably precisely why they favour this technique. A good example of this is the 'fight' against irregular migration: most States do not have statistics, nor official estimates of the undocumented population. Quite often, when a new smuggling operation is uncovered, the minister will announce a change in the law, although everyone knows that measuring the results of the change will be difficult or impossible.

Another example of politicians' speech acts is the outright criticism of the mandate holders' reports, without engaging on the content of the analysis or the recommendations. Politicians will easily argue that (a) other countries require more attention than they do; (b) the objects of the reports are not human rights concerns or at least are not the concern of UN human rights mechanisms; (c) mandate holders have gone beyond the scope of their duties; and (d) mandate holders' visits are politicised. We will now explore those arguments as they all have some appearance of merit that must be addressed before bringing about a rebuttal.

\section{A. Other countries require more attention}

One reason that Global North States may be obstructive when it comes to mandate holders' reports is that they consider that their human rights records are a cut above those of Global South countries. Although those States pay lip-service to universality, in practice they are adamant that mandate holders ought to focus their efforts elsewhere. They essentially consider that universality does not apply to them because they implement rights to a greater 
extent than other States. That interpretation of universality focuses on priorities rather than on universality being that everyone can be legitimately scrutinised.

That argument may easily be rebutted. At the heart of international human rights is their universal nature. Rights apply to all individuals regardless of race, religion, nationality, gender, sexuality or any other characteristic. All countries can improve their human rights records. From Sweden to Somalia, from Norway to North Korea, there is a need to protect and promote human rights. If the UN only focussed on States with the most acute problems, then individuals in more developed countries would be afforded no protection. And, crucially, if the UN only focussed on some States or regions, then the legitimacy of the Special Procedures system - based on its universality - would wholly be undermined.

B. These are not human rights, or UN mechanisms', concerns

The argument about whether ESCR, TGR and some vulnerable groups fall within international human rights law and its mechanisms is a return to the issue of ideologies. As set out in Section 2, many Global North States afford lesser legal protection to ESCR and TGR than to CPR. Despite many of those States formally committing to the principle of interdependence and indivisibility of rights, there is a continuing ideological divide regarding whether ESCR and TGR rights are legal or whether they are political matters which should not be justiciable before courts or tribunals, and thus better left to the expert appreciation of politicians and civil servants.

Of course, those arguments are well-worn and have long been rebutted within the international human rights law arena and yet are invoked by State representatives that have little or no expertise in this subject. Both CPR and ESCR require States to take positive steps to ensure that the rights are implemented and realised. Both CPR and ESCR are justiciable, and therefore may be addressed by legal mechanisms as the case law of several constitutional or supreme courts attest. Both CPR and ESCR contain issues that are political but the role of courts, tribunals and other human rights enforcement mechanisms remains to ensure that standards and practices remain within the bounds of the human rights framework. The artificial distinctions between these types of rights have comprehensively been dealt with at conceptual level, yet they are wheeled out by politicians and government representatives when policies are challenged or examined by mandate holders, if it is deemed politically beneficial to do so.

C. Mandate holders have gone outside of the scope of their mandates 
The arguments that mandate holders have gone outside of the scope of their mandates or have visited without permission demonstrate a fundamental lack of knowledge and understanding of how such visits are conducted. Mandate holders may only visit a country if that State formally agrees to a visit request. Any visit requires a great deal of coordination with the country's government in order to set up meetings with ministers, government departments, civil servants, national human rights institutions, citizens and many other actors. It is never the case that a Special Rapporteur just turns up unannounced. Ample opportunities exist for a country either tacitly or expressly to block a visit. Indeed, many countries have blocked visits. ${ }^{126}$ Some have simply ignored requests to coordinate visits; others have refused to issue visas; while some States have failed to comply with SP mandate holders' terms of reference by blocking access to State and non-state actors.

Global North States are correctly commended for almost always accepting mandate holders' visit requests. Those countries typically, with few exceptions, allow mandate holders to have free and unfettered access to conduct fact-finding as part of those missions. Yet, when they accuse experts of going beyond their mandates, government representatives undermine the credibility and legitimacy of mandate holders in terms of their other countryspecific or, indeed, thematic reports. By resisting criticisms of their own domestic human rights records, Global North countries lay the foundations for other countries - particularly known human rights abusers - to do the same.

\section{Visits are politicised}

The final argument that must be addressed is whether mandate holders' visits are politicised. Proportionately, there is a high percentage of visits to Global North States compared with Global South countries. It must first be borne in mind that many Global South States do not have standing invitations, or, even if they do, they refuse visits. Global North States do accept all invitations and therefore bear a disproportionate burden in terms of visits. Those countries represent 75 per cent of the world's wealth and less than 20 per cent of the world's population, and they approximately shoulder between one third and one half of mandate holders' visits. It is to the credit of those States that they receive so many mandate holders.

At the same time, the reports frequently provide best practices to which other countries may refer and implement. They also provide crucial information-sharing and factfinding to be used by civil society and other actors in other States. Moreover, and of

${ }^{126}$ For more on this point, see Gaer's contribution to this volume. 
particular importance, by conducting visits to Global North countries, mandate holders are able to counter the loud and increasingly-voiced mantra that UN human rights mechanisms, and indeed international human rights law more generally, is a "neo-colonial tool of oppression ${ }^{127}$ used by the Global North against the Global South.

\section{Moving forward}

The point of this chapter has been to expose the negative ways in which some Global North States respond to some Special Procedures mandate holders, and the forms that such responses take. Our aim has been to highlight and analyse this issue in order for it to be addressed so that Special Procedures can be strengthened and not undermined. Questions must be asked as to whether Global North States' engagement with Special Procedures, through allowing mandate holders to visit, is undermined when they criticise or sometimes altogether ignore a report and its recommendations by failing to engage with the substance of mandate holders' conclusions and suggestions. Indeed, it could be said that there is little practical difference - other than the information-sharing aspect - between the way those States engage with mandate holders and countries that simply refuse to allow mandate holders to visit. After all, governments change while reports remain, and what has been criticised by the government of the day may become the doctrine of a future government.

Conclusions that can be drawn - prior to further qualitative and quantitative research being undertaken on this topic - point towards the central importance of these types of visits to and reports on Global North States. The heavy criticism of the reports considered in this chapter can be interpreted as a sign that the mandate holders have touched upon nerves that already are raw. The reports highlight and emphasise crucial human rights issues that those governments devote significant time and resources to presenting as matters that fall within policy parameters rather than ones that require legal mechanisms for their protection. The reports also provide crucial resources to civil society organisations, grassroots activists and legal practitioners, and are picked up on by other international human rights mechanisms which use the reports and recommendations as a basis for questioning and probing States as well as focusing on specific issues highlighted by SP mandate holders. Lastly, the media has become more aware of and more engaged with SP mandate holders as a direct result of governmental outbursts and negative responses to certain visits and reports, thus ensuring greater interest and dissemination of mandate holders' work.

\footnotetext{
${ }^{127}$ P Alston, 'Reconceiving the UN Human Rights Regime: Challenges Confronting the New UN Human Rights Council’ (2006) 7 Melbourne Journal of International Law 185, 205-206.
} 
